\title{
Correction to: Liposomal Irinotecan: A Review in Metastatic Pancreatic Adenocarcinoma
}

\author{
James E. Frampton ${ }^{1}$ \\ Published online: 3 July 2020 \\ (c) Springer Nature 2020
}

\section{Correction to: Drugs (2020) 80:1007-1018 https://doi.org/10.1007/s40265-020-01336-6}

The article Liposomal Irinotecan: A Review in Metastatic Pancreatic Adenocarcinoma, written by James E. Frampton, was originally published Online First without Open Access. After publication in volume 80, issue 10, pages 1007-1008 Servier Affaires Medicales requested that the article be Open Choice to make the article an open access publication. Post publication open access was funded by Servier Affaires Medicales. This article is licensed under a Creative Commons Attribution-NonCommercial 4.0 International License, which permits any non-commercial use, sharing, adaptation, distribution and reproduction in any medium or format, as long as you give appropriate credit to the original author(s) and the source, provide a link to the Creative Commons licence, and indicate if changes were made. The images or other third party material in this article are included in the article's Creative Commons licence, unless indicated otherwise in a credit line to the material. If material is not included in the article's Creative Commons licence and your intended use is not permitted by statutory regulation or exceeds the permitted use, you will need to obtain permission directly from the copyright holder. To view a copy of this licence, visit https://creativecommons .org/licenses/by-nc/4.0/.

The original article has been corrected.

Open Access This article is licensed under a Creative Commons Attribution-NonCommercial 4.0 International License, which permits any non-commercial use, sharing, adaptation, distribution and reproduction in any medium or format, as long as you give appropriate credit to the original author(s) and the source, provide a link to the Creative Commons licence, and indicate if changes were made. The images or other third party material in this article are included in the article's Creative Commons licence, unless indicated otherwise in a credit line to the material. If material is not included in the article's Creative Commons licence and your intended use is not permitted by statutory regulation or exceeds the permitted use, you will need to obtain permission directly from the copyright holder. To view a copy of this licence, visit http://creativecommons.org/licenses/by-nc/4.0/.
The original article can be found online at https://doi.org/10.1007/ s40265-020-01336-6.

James E. Frampto

demail@springer.com

1 Springer Nature, Mairangi Bay, Private Bag 65901, Auckland 0754, New Zealand 